\title{
Iphan e Fundação Catarinense de Cultura: políticas para o patrimônio cultural do imigrante europeu em Santa Catarina na década de 1980
}

Iphan and Fundação Catarinense de Cultura: policies for immigrant cultural heritage in 1980s Santa Catarina

https://doi.org/10.1590/1982-02672020v28d2e53

\section{DANIELA PISTORELLO'}

https: / / orcid.org/0000-0002-9102-4766

Universidade da Região de Joinville / Joinville, SC, Brasil

RESUMO: O objetivo deste artigo é problematizar as políticas de preservação do patrimônio cultural do imigrante europeu em Santa Catarina durante a década de 1980. Para tanto, será analisada parte das ações empreendidas pelo Instituto do Patrimônio Histórico e Artístico Nacional (Iphan) e pela Fundação Catarinense de Cultura (FCC) que culminaram na formação dos Roteiros Nacionais de Imigração. Esse projeto definiu, por meio de ações de salvaguarda do patrimônio cultural, qual era o lugar do patrimônio do imigrante e como se daria sua preservação no Brasil e em Santa Catarina. $\bigcirc$ artigo destaca ainda como o imigrante - e, consequentemente, seu patrimônio - adquiriu valor dentro da política de preservação estadual de forma a construir, para o estado catarinense, uma perspectiva de patrimônio cultural calcada essencialmente em questões étnicas.

PALAVRAS-CHAVE: Política pública de preservação do patrimônio. Roteiros Nacionais de Imigração. Santa Catarina.

ABSTRACT: This paper discusses heritage cultural preservation policies of European immigrants in 1980s Santa Catarina. We analyze the actions of Instituto do Patrimônio Histórico e Artístico Nacional (Iphan) and Fundação Catarinense de Cultura (FCC) that result in the formation of the National Immigration Routes project. By verifying the actions taken to safeguard cultural heritage,

\begin{abstract}
1. Graduou-se em História pela Universidade Federal de Santa Maria e é mestre pela Pontifícia Universidade Católica do Rio Grande do Sul. Realizou doutorado-sanduíche na Universidade Politécnica da Catalunha (Espanha), obtendo título de doutora em História pela Universidade Estadual de Campinas. Realizou estágio pós-doutoral na Universidade do Estado de Santa Catarina. É membro do Comitê Brasileiro para Conservação do Patrimônio Industrial e bolsista PNPD/Capes do Programa de Pós-Graduação em Patrimônio Cultural e Sociedade da Universidade da Região de Joinville. E-mail: <danipistorello@ hotmail.com>.
\end{abstract}


this project defined the role of immigrant heritage and determined how its preservation in Brazil and Santa Catarina should be carried out. This paper also describes how immigrants and their heritage started being valued in the context of the governmental preservation policy so as to develop a perspective of cultural heritage in Santa Catarina essentially based on ethnic issues.

KEYWORDS: Heritage preservation public policies. National immigration routes project. Santa Catarina. 
O estado de Santa Catarina passou a ter maior visibilidade nacional, em termos patrimoniais, a partir do projeto Roteiros Nacionais de Imigração, lançado em Pomerode (SC) pelo Instituto do Patrimônio Histórico e Artístico Nacional (Iphan) em 2007.2

Esse projeto, que nasceu em solo catarinense e foi planejado para se expandir a outros estados brasileiros, resultou de um consórcio entre o Iphan, a Fundação Catarinense de Cultura (FCC) e dezesseis municípios de Santa Catarina. Seu objetivo era inventariar o patrimônio cultural do imigrante no estado, tombar os bens culturais considerados significativos do processo de migração nos três níveis administrativos e instituir rotas e/ou roteiros turísticos que valorizassem esses bens culturais e trouxessem algum benefício para as localidades em questão. ${ }^{3}$

Uma das justificativas para que esse projeto se iniciasse em Santa Catarina era a de valorizar e potencializar o vasto trabalho de pesquisa e os levantamentos realizados pela FCC desde 1980, que apontavam, em linhas gerais, a importância do patrimônio de imigrantes alemães e italianos no estado. Em 3 de maio de 2011 , na $67^{a}$ Reunião do Conselho Consultivo do Iphan, foi aprovado o tombamento de 61 bens identificados como patrimônio cultural de alemães, italianos, poloneses e ucranianos presentes nessa unidade federativa. Meses depois, em um processo que ainda provoca dúvidas, também foi atribuída a primeira Chancela da Paisagem Cultural Brasileira ao núcleo colonial que abrange as localidades de Testo Alto, em Pomerode, e de Rio da Luz, em Jaraguá do Sul - áreas que correspondem ao projeto Roteiros Nacionais de Imigração. A área de abrangência do Projeto e seus principais objetivos podem ser visualizados na Figura abaixo:
2. O lançamento do projeto Roteiros Nacionais de Imigração se constituiu em um evento de ampla divulgação na mídia regional e nacional. A cerimônia contou com a presença do então ministro da Cultura, Gilberto Gil; com a participação do vice-governador de Santa Catarina, Leonel Pavan; do secretário de Estado de Turismo, Cultura e Esporte, Gilmar Knaesel; do diretor do Departamento de Patrimônio Material e de Fiscalização do Iphan, Dalmo Vieira Filho; do representante do Ministério do Desenvolvimento Agrário, Jurandir Teodoro; da ministra do Turismo, Tânia Brizola; do diretor administrativo do Sebrae de Santa Catarina, José Alaor Bernardes; e do prefeito de Pomerode, Ércio Kriek; além de deputados federais, estaduais, cônsules, conselheiros estaduais da Cultura, prefeitos e demais autoridades. $\mathrm{Na}$ oportunidade, o projeto foi apresentado à sociedade brasileira como iniciativa pioneira dentro do que se propunha, dando visibilidade nacional ao estado de Santa Catarina.

3. Instituto do Patrimônio Histórico e Artístico Nacional (2011). 


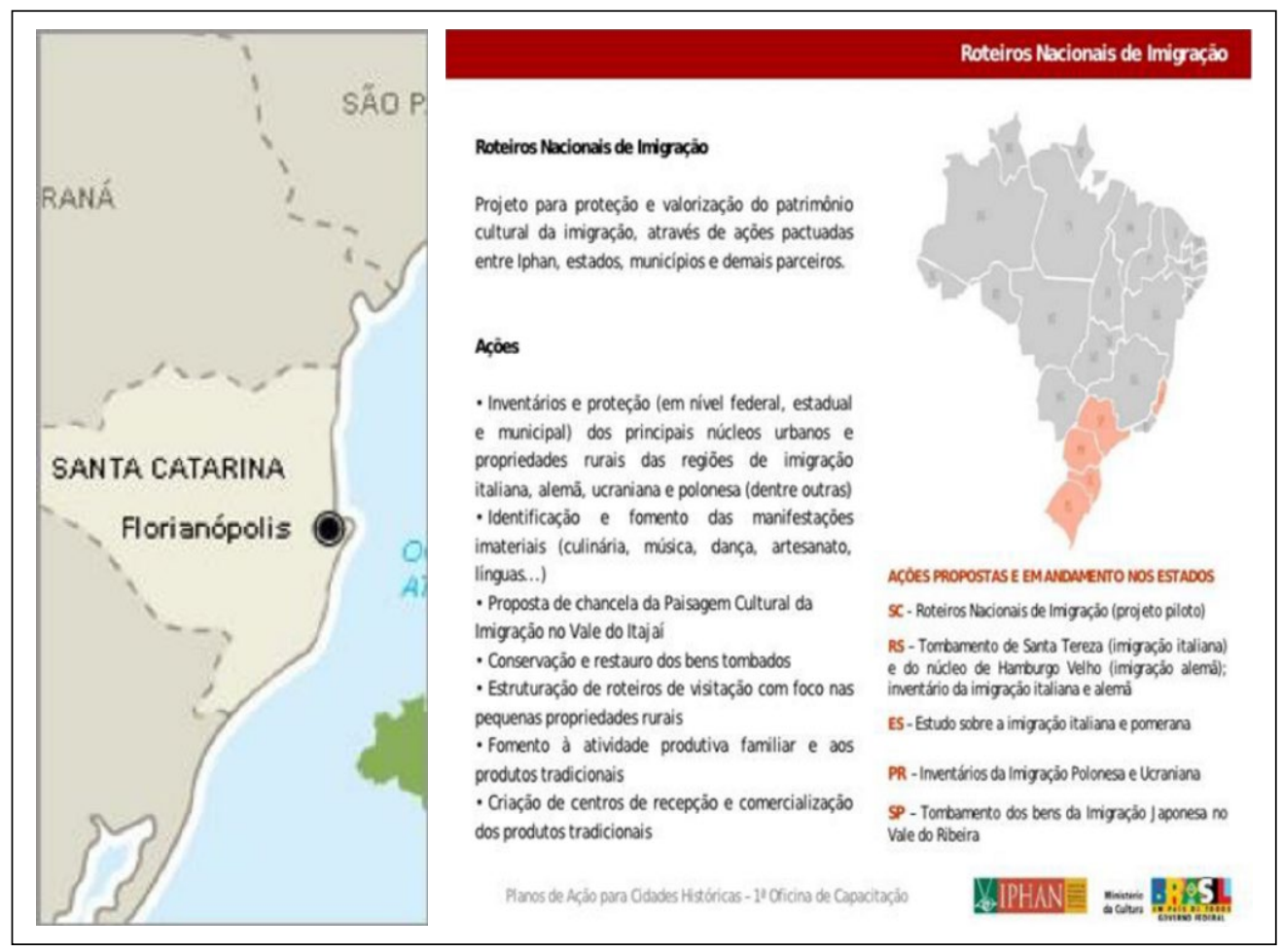

Figura 1 - Localização e abrangência do projeto Roteiros Nacionais de Imigração de Santa Catarina. Fonte: adaptado pela autora de Iphan (2009).

Esse projeto, que deu maior visibilidade ao estado de Santa Catarina e até então estava ausente nos debates mais substanciais sobre a preservação do patrimônio cultural do imigrante europeu, construiu a identificação do patrimônio catarinense valorizando o caráter étnico, característica presente nas ações de preservação empreendidas pela FCC desde os anos 1980.

Interessa aqui perceber como as instituições responsáveis pela atribuição de valor aos bens relativos ao imigrante e seus agentes ressignificaram esse patrimônio ao longo do tempo, uma vez que as formas de o perceber mudaram, e mudam constantemente, dotando-o de uma dinâmica que permite problematizar seus diversos sentidos. Assim, este artigo trata das formas pelas quais o patrimônio do imigrante foi apropriado ao longo do tempo pelo órgão de preservação nacional a partir das políticas de proteção do patrimônio cultural de Santa Catarina na década de 1980, além de buscar compreender qual imigrante foi contemplado por essas políticas, quais valores foram atribuídos ao seu patrimônio e de que forma estes foram incorporados ao projeto Roteiros Nacionais de Imigração. 
Parte do patrimônio do imigrante europeu estabelecido no Brasil no século XIX pode ser conhecida graças à sua preservação. Obviamente, a importância do seu legado vai além do seu reconhecimento pelo Estado (neste caso, representado pelo (phan) e dos sentidos institucionais que se the atribuem. Afinal, a preservação dos bens patrimoniais é parte da política cultural de uma nação, que institui formalmente quais e de que maneira as memórias devem ser selecionadas em detrimento daquelas que devem ser esquecidas e/ou silenciadas.

Perceber os valores atribuídos aos bens culturais - neste caso específico, ao patrimônio do imigrante - é perceber o próprio sentido que a preservação assume ao longo do tempo, pois:

falar e cuidar de bens culturais não é falar de coisas ou práticas em que tenhamos identificado significados intrínsecos, próprios das coisas em si, obedientemente embutidos nelas, mas é falar de coisas (ou práticas) cujas propriedades, derivadas de sua natureza material, são seletivamente mobilizadas pelas sociedades, grupos sociais comunidades, para socializar, operar e fazer agir suas ideias, crenças, afetos, seus significados, expectativas, juízos, critérios, normas, etc., etc., - e, em suma, seus valores. [...] a matriz desses sentidos, significações e valores não está nas coisas em si, mas nas práticas sociais. ${ }^{4}$

Corroborando tal compreensão, Márcia Chuva infere que dotar o bem cultural de valor patrimonial, ou seja, patrimonializá-lo, é:

selecionar um bem cultural (objetos e práticas) por meio da atribuição de valor de referência cultural para um grupo de identidade. $O$ bem patrimonializado tem como atributo a capacidade de amalgamar grupos de identidade. [...] A patrimonialização de práticas culturais [...] promove a concorrência e, por vezes, a dissenção entre grupos, vivenciada através de tensões e disputas, num contexto de lutas de representação, lutas por legitimidade e lutas políticas, que redundam em disputa por recursos direta ou indiretamente. ${ }^{5}$

Neste sentido, as reflexões apresentadas neste artigo pretendem responder: que políticas estaduais empreendidas nos anos 1980 são essas e de que forma contribuíram para construir, no território catarinense, um patrimônio calcado em perspectivas étnicas, especificamente de alguns imigrantes europeus, como apresentou o projeto Roteiros Nacionais de Imigração?

Considera-se, para responder à questão, a ideia de patrimônio como campo de tensões. A noção de campo, conforme Bourdieu, é concebida como um espaço social multidimensional de relações entre agentes que compartilham interesses em comum, mas não dispõem dos mesmos recursos. Todo campo é "um campo de forças", 
6. Bourdieu (1996, p. 50).

7. A valorização do patrimônio do imigrante europeu não se dá somente através da instituição do tombamento. Podese citar outras duas formas de salvaguarda que permitem inferir sobre sua valorização ao longo do tempo: a chancela de paisagem cultural, cuja primeira atribuição foi conferida às localidades de imigração europeia no estado de Santa Catarina (representadas pelo núcleo rural de Testo Alto e Rio da Luz), e a titulação do talian (dialeto dos imigrantes italianos na Serra Gaúcha) como referência cultural. pois constrange os agentes nele inseridos, assim como um "campo de lutas", no qual os agentes atuam conforme suas posições, mantendo ou modificando sua estrutura. ${ }^{6}$

A metodologia empregada para atingir os objetivos aqui propostos considera a análise das ações implementadas pela FCC e pelo Iphan em Santa Catarina, representadas por alguns dos projetos realizados nos anos 1980, selecionados para este fim. Para tanto, este artigo apresenta, em um primeiro momento, as práticas de preservação do patrimônio do imigrante no Brasil e, em um segundo momento, percebe como Santa Catarina empreendeu as políticas de preservação desse patrimônio no estado. Por fim, também analisa essas práticas à luz das políticas públicas de preservação dos anos 1980.

\section{O LUGAR DO PATRIMÔNIO DO IMIGRANTE NO BRASIL}

Ao se observar o trabalho do lphan ao longo dos quase oitenta anos desde a promulgação do Decreto-Lei $n^{\circ} 25$, de 30 de novembro de 1937, percebe-se que, mesmo tímida, a valorização do patrimônio do imigrante europeu está presente desde os primeiros anos de atuação da instituição no sul do país. Ela tomou vulto nos anos 1980 e ganhou expressão em 2007 com o lançamento do projeto Roteiros Nacionais de Imigração de Santa Catarina, conforme se pode verificar nos dados relativos aos tombamentos destes bens (Quadro 1).

\begin{tabular}{|c|c|c|c|c|}
\hline Processo & Bem & Localização & Livro Tombo & Ano \\
\hline Processo 161-T-38 & Palácio dos Príncipes & Joinville-SC & Belas Artes, Histórico & 1939 \\
\hline Processo 659-T-62 & Cemitério Protestante & Joinville-SC & $\begin{array}{c}\text { Histórico, Arqueoló- } \\
\text { gico/Etnográfico/ } \\
\text { Paisagístico }\end{array}$ & 1962 \\
\hline Processo 756-T-65 & Bosque Schmalz & Joinville-SC & $\begin{array}{c}\text { Histórico, Arqueoló- } \\
\text { gico/Etnográfico/ } \\
\text { Paisagístico }\end{array}$ & 1965 \\
\hline Processo 1 1 1 13-T-84 & Casa Presser & Novo Hamburgo-RS & $\begin{array}{c}\text { Belas Artes, Histórico, } \\
\text { Arqueológico/Etno- } \\
\text { gráfico/Paisagístico }\end{array}$ & 1984 \\
\hline Processo 1 124-T-84 & Casarão do Chá & Mogi das Cruzes-SP & $\begin{array}{c}\text { Belas Artes, Histórico, } \\
\text { Arqueológico/Etno- } \\
\text { gráfico/Paisagístico }\end{array}$ & 1984 \\
\hline
\end{tabular}




\begin{tabular}{|c|c|c|c|c|}
\hline Processo & Bem & Localização & Livro Tombo & Ano \\
\hline Processo 1 141-T-85 & $\begin{array}{c}\text { Casa do Professor e } \\
\text { Escola Rural }\end{array}$ & Rio dos Cedros-SC & $\begin{array}{c}\text { Belas Artes, Histórico, } \\
\text { Arqueológico/Etno- } \\
\text { gráfico/Paisagístico }\end{array}$ & 1985 \\
\hline Processo 1 145-T-85 & Casa da Neni & Antônio Prado-RS & Belas Artes & 1985 \\
\hline Processo 1 165-T-85 & Ponte do Imperador & Ivoti-RS & Histórico & 1985 \\
\hline Processo 1248-T-87 & Conjunto Urbano & Antônio Prado-RS & $\begin{array}{c}\text { Histórico, Arqueoló- } \\
\text { gico/Etnográfico/ } \\
\text { Paisagístico }\end{array}$ & 1990 \\
\hline Processo 1548-T-07 & $\begin{array}{c}\text { 61 Bens dos Roteiros } \\
\text { Nacionais de } \\
\text { Imigração de Santa } \\
\text { Catarina }\end{array}$ & Várias Cidades-SC & $\begin{array}{c}\text { Registros em vários } \\
\text { Livros }\end{array}$ & 2011 \\
\hline
\end{tabular}

Quadro 1 - Tombamentos do Iphan relativos ao patrimônio do imigrante europeu. Fonte: Adaptado pela autora de Weissheimer; Vieira (2011)

Historicamente, o reconhecimento do legado cultural do patrimônio do imigrante como parte do patrimônio histórico brasileiro pelos órgãos de preservação teve início a partir de 1939, contando com ações de salvaguarda em São Paulo, no Rio Grande do Sul e em Santa Catarina.

Os primeiros tombamentos de relevância nacional do patrimônio do imigrante europeu em Santa Catarina foram o do Palácio dos Príncipes, em 1939, e, após três décadas, do Cemitério Protestante e do Bosque Schmalz, todos em Joinville. Percebe-se, portanto, que antes dos anos 1980 - recorte proposto por este dossiê - houve três tombamentos ligados ao patrimônio do imigrante, todos localizados em uma mesma cidade catarinense.

O primeiro deles, o Palácio dos Príncipes, dificilmente seria identificado como bem cultural ligado à imigração alemã caso o processo se restringisse à sua denominação. Apesar de nunca ter servido de residência imperial da família Orléans - como seu nome indica -, o casarão, construído como sede da administração da Colônia Dona Francisca, foi tombado pelo órgão federal em 1957 e, desde então, se dedica a recolher objetos e documentos relacionados ao processo histórico da imigração e colonização. Já que nesse processo não consta a documentação relativa ao bem, como é o caso dos processos mais antigos, não se pode saber quais argumentos endossaram sua importância. Percebe-se que, muito embora o valor atribuído ao casarão seja devido a sua relação com a imigração na cidade, a questão étnica ficou ausente na sua nomenclatura, privilegiando uma memória ligada à família imperial, ainda que nunca tivesse sido residência desta. 
8. Instituto do Patrimônio Histórico e Artísitico Nacional (1962, fl. 15).

9. Ibid. (fl.16).

10. Radum (2016)

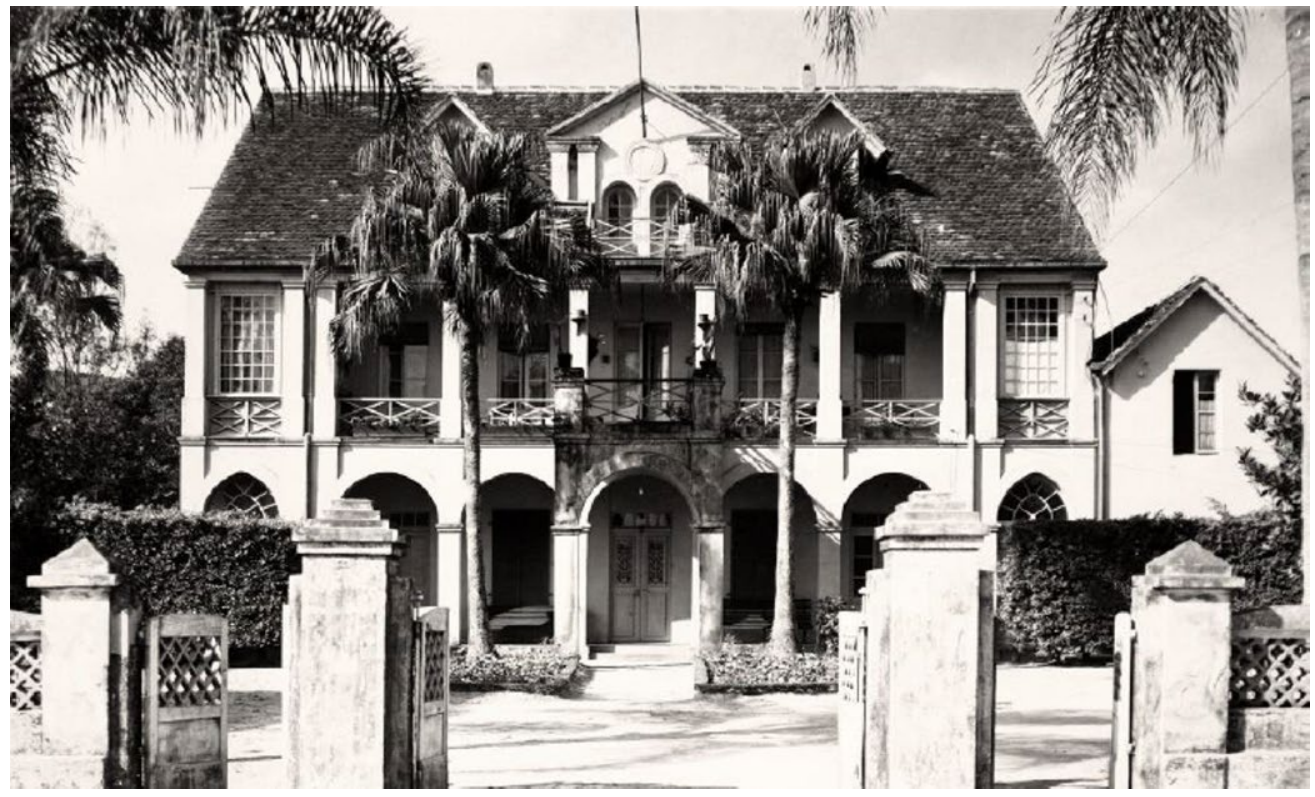

Figura 2 - Palácio dos Príncipes, antiga sede do Domínio Dona Francisca na Colônia Dona Francisca. Fonte: Álbum fotográfico do Centenário de Joinville, de 1951, do acervo do Arquivo Histórico de Joinville.

O segundo tombamento federal em Joinville, na década de 1960, foi o do Cemitério Protestante, solicitado por Carlos Ficker e reiterado pela prefeitura, pois "representa sem dúvida um monumento histórico para estudos genealógicos e ao mesmo tempo é um dos recantos mais belos da cidade, com árvores seculares e uma vista deslumbrante sobre a antiga Colônia Dona Francisca, hoje Joinville". 8

Foi um parecer de Lúcio Costa que atestou a importância do bem em esfera nacional, atribuindo relevância à paisagem que conforma o cemitério. Não se tratava de qualquer paisagem, mas daquela compreendida como sinônimo de natureza intocada, dotando o lugar de um ar bucólico, romântico, e dando-the a impressão de "cultivado abandono".9

O terceiro bem tombado, é o hoje denominado Bosque Schmalz, declarado em 1965 como patrimônio paisagístico nacional. Denis Fernando Radum, em sua dissertação de mestrado defendida em 2016, intitulada $\bigcirc$ (des)tombamento em questão: (des)patrimonialização de bens culturais tombados pelo órgão federal de preservação no Brasil (1937-2015), ocupou-se de analisar os processos de tombamento e destombamento do Bosque, chamando a atenção para os argumentos utilizados na fundamentação do pedido de tombamento desse bem: ele guardava um último resquício de mata virgem e remetia aos tempos dos primeiros colonizadores. ${ }^{10}$ Seu tombamento era, portanto, uma "homenagem à 
dedicação e ao empenho dos antigos colonizadores que tanto contribuíram para o desenvolvimento e a civilização do sul do país". ${ }^{11}$
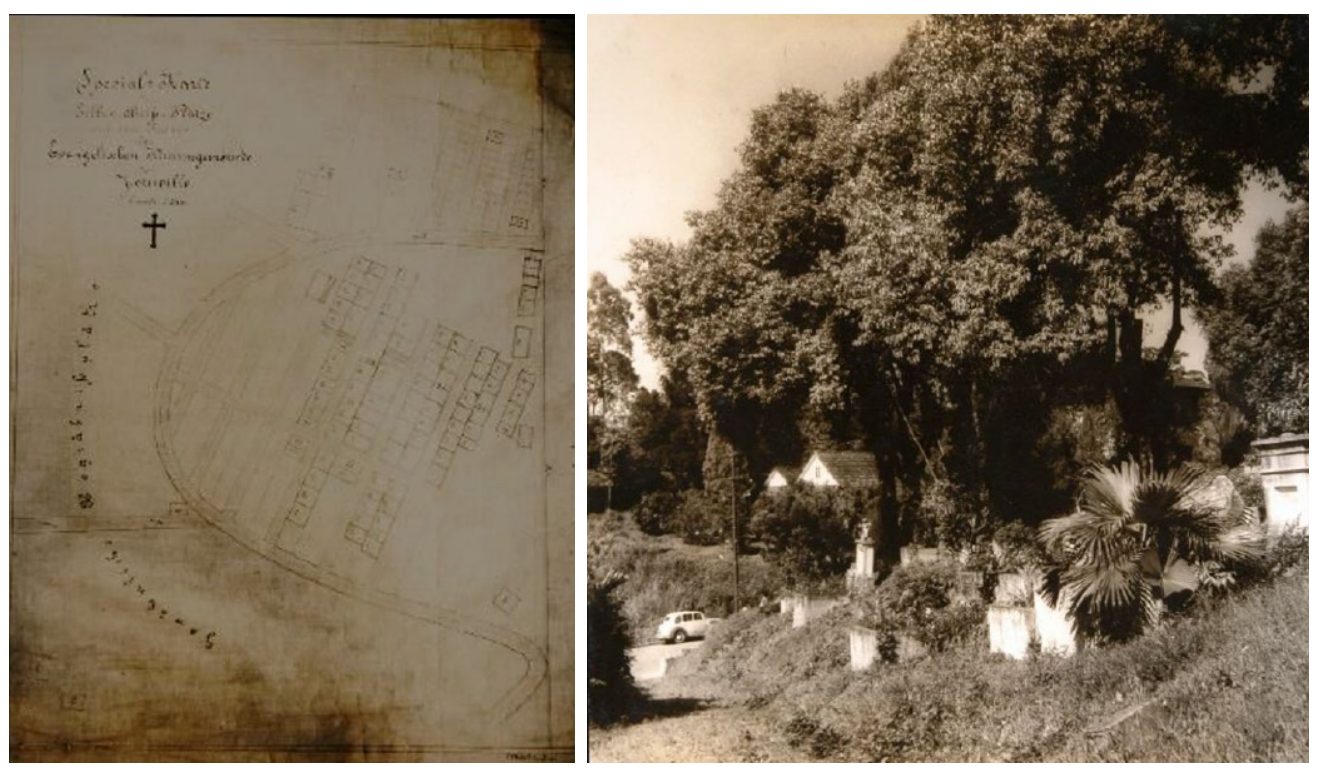

Figura 3 - Cemitério Protestante de Joinville. Fonte: Iphan (1962).

Esses três tombamentos de Joinville ganharam espaço em um contexto no qual o patrimônio cultural esteve ligado exclusivamente ao passado colonial do Brasil. Que valores thes foram atribuídos para que pudessem ser relevantes na composição de uma identidade para o Brasil? A este respeito cabem três observações.

A primeira se refere ao tombamento realizado em 1939, do Palácio dos Príncipes, que não associou o bem à imigração alemã diretamente. Ora, para o Estado Novo, o "outro" era o próprio inimigo da construção de uma identidade nacional, que deveria acabar com os regionalismos. O patrimônio deveria representar a nação como resultado da marcha universal dos Estados nacionais rumo ao "progresso".

Nesse sentido, o patrimônio era concebido como instrumento para educar a população a respeito da unidade e da permanência da nação, conforme sugere Márcia Chuva. ${ }^{12}$ No entanto, como aponta Silvana Rubino, ${ }^{13}$ o fato de o Serviço do Patrimônio Histórico e Artístico Nacional (Sphan) ter sido criado sob a égide do Estado Novo, mas não ser o reflexo deste, permitiu que se observasse a importância arquitetônica das edificações - ainda que silenciando, de forma proposital ou não, questões sobre seu uso e seus construtores e/ou habitantes.

A segunda observação é relativa ao momento no qual o Palácio dos Príncipes de Joinville é reconhecido como Museu Nacional da Imigração e da Colonização.
11. Instituto do Patrimônio Artístico Nacional (1965, fl. 120).

12. Chuva (2009).

13. Rubino (1991). 
14. Ibid. (p. 156-157).

15. Machado (2019).
Em 1946, o Decreto-Lei nº 8.534 transformou o Sphan em Diretoria do Patrimônio Histórico e Artístico Nacional (Dphan). Além de instituir distritos em quatro municípiossede, essa Diretoria criou, pela Lei n 3.188, de 12 de junho de 1957, o Museu Nacional da Imigração e da Colonização em Joinville para recolher objetos que recordassem a imigração no sul do país. Silvana Rubino aponta que esse museu

traz, junto com novos personagens dignos de salvaguarda, novas disciplinas para abordá-los. Marca assim um novo período do Sphan, menos patriótico e mais investigador a respeito de ancestrais virtuais do brasileiro, que antes, no período de Getúlio Vargas e Gustavo Capanema, não seriam incluídos. ${ }^{14}$

Ainda que o historiador Diego Machado tenha chamado a atenção para as muitas controvérsias relacionadas à criação do Museu Nacional da Imigração e da Colonização em Joinville, ${ }^{15}$ observa-se que houve um deslocamento na forma de perceber o imigrante e seu patrimônio no que diz respeito à sua participação na formação nacional. Se até a emergência da Segunda Guerra esse imigrante representava um perigo à ordem nacional e não teve sequer seu patrimônio nominado, a década de 1950 "reabilitou", de certa forma, sua participação na sociedade brasileira, reconhecendo a importância de seu patrimônio como parte da identidade nacional.

A terceira observação é relativa ao tombamento do Cemitério Protestante, realizado em 1962. Ainda sob a direção de Rodrigo Mello Franco de Andrade, a Dphan acolheu a indicação, valorizando o sentido histórico da antiga Colônia Dona Francisca, bem como as obras realizadas pelos imigrantes alemães naquela região - observação que vale também para o tombamento do Bosque Schmalz. No entanto, a justificativa para o tombo se pautou pelo "ar romântico" do cemitério, que tinha um cenário de "cultivado abandono", nos dizeres de Lúcio Costa. $\bigcirc$ processo foi marcado mais pela ação da natureza - que deveria ser preservada - do que pela história dos imigrantes, passível de problematização nesse espaço.

Os anos que separam os primeiros tombamentos relativos ao patrimônio do imigrante dos que ocorreram a partir dos anos 1980 viram transformações significativas no campo do patrimônio no Brasil e correspondem ao período no qual Renato Soeiro esteve à frente do Iphan (de 1967 a 1979). Embora não tenha sido muito valorizado pela história da própria instituição, uma das ações implementadas sob sua administração teve importância significativa: a criação do Centro Nacional de Referências Culturais (CNRC), presidido por Aloísio Sérgio Magalhães. $O$ CNRC possibilitou, entre outras coisas, a criação do chamado 
Museu ao Ar Livre de Orleans, em 1980, que produziu impactos na forma de pensar o patrimônio do imigrante no estado catarinense.

Através do Decreto-Lei nº 84. 198, de 13 de novembro de 1979, o presidente da República instituiu a Secretaria do Patrimônio Histórico e Artístico Nacional (Sphan) e a Fundação Nacional Pró-Memória, e transferiu a responsabilidade de execução do Programa Cidades Históricas para essa organização. A preservação do acenvo cultural e paisagístico brasileiro passou a ser competência da Sphan, e a Fundação Nacional Pró-Memória ficou incumbida de providenciar os recursos demandados pela Secretaria. Aloísio Sérgio Magalhães, criador e diretor-geral do CNRC, foi nomeado seu diretor. ${ }^{16}$ Ele levou ao órgão duas novas orientações que não eram seguidas pela direção anterior: a participação ativa da comunidade à qual o bem cultural pertencia e a ampliação do conceito de patrimônio. Até aquele momento, esse conceito se concentrava exclusivamente nos monumentos da cultura que conformavam uma tradição europeia, tornando problemática uma identificação social mais abrangente e relegando todo um acervo de expressões culturais ligadas aos demais grupos sociais. Os novos horizontes patrimoniais trazidos pela experiência do CNRC possibilitaram temáticas e questões que passaram a ser consideradas pelas políticas de patrimônio nacionais.

Na gestão de Aloísio Magalhães, o órgão de preservação começou a valorizar outras expressões culturais, entre elas o legado do imigrante e o seu patrimônio. Segundo Maria Regina Weissheimer, ${ }^{17}$ foi apenas nessa década que se investiv em estudos e mapeamentos amplos relacionados à temática da imigração no sul do Brasil. Isso se deu através do inventário realizado pela $10^{a}$ Diretoria da Sphan, em conjunto com a Secretaria do Desenvolvimento Regional e Obras Públicas do Rio Grande do Sul, para levantar o acervo cultural dos municípios da região de imigração italiana do estado, ${ }^{18}$ como também por meio dos trabalhos realizados pelo arquiteto Günter Weimer ${ }^{19}$ sobre a arquitetura teuto-brasileira no Rio Grande do Sul.

Nessa mesma época, a administração gaúcha articulou o projeto Preservação e Valorização da Paisagem Urbana com Núcleos da Imigração Alemã e Italiana no Rio Grande do Sul, que envolvia diversas secretarias do estado, o Iphan e o Instituto Gaúcho de Tradição e Folclore. Tal movimentação culminou, em 1983, com a formação de um grupo de trabalho que reunia funcionários do Iphan e do governo do Rio Grande do Sul, ${ }^{20}$ sendo este o responsável pelo tombamento da Casa Neni (1985), em Antônio Prado (complementado pelo tombamento do conjunto urbano da arquitetura ítalo-brasileira de madeira, na mesma cidade, em 1990); da Casa Presser (1984), em Novo Hamburgo; da Ponte do Imperador
16. Fonseca (2005).

17. Weissheimer (2012, p 225).

18. Instituto do Patrimônio Histórico e Artísitico Nacional (1990, fl. 7).

19. Weimer (2005).

20. Instituto do Patrimônio Histórico e Artísitico Nacional (2009, p. 20). 
21. Rio Grande do Sul e Santa Catarina contaram com a representação do Iphan e trabalharam, por algum tempo, sob a mesma direção. Em Porto Alegre, o órgão se fez presente desde 1939, quando era subordinado administrativamente ao $4^{\circ}$ Distrito da Dphan, com sede em São Paulo, até 1978, quando foi criada a Representação Regional com jurisdição sobre o Rio Grande do Sul e Santa Catarina. Este último estado esteve subordinado administrativamente à $10^{\mathrm{a}}$ Diretoria Regional, com sede em São Paulo, até 1989, quando foi criada a $12^{\mathrm{a}}$ Diretoria Regional, que em 1990 recebeu a denominação de $11^{\mathrm{a}}$ Coordenação Regional. Esta foi denominada $11^{\text {a }}$ Superintendência Regional até 2009 e atualmente representa a Superintendência Estadual do Iphan em Santa Catarina. Por esse motivo, muitas das discussões, decisões e documentações sobre tombamentos federais no estado de Santa Catarina fazem referência ao escritório em Porto Alegre.

22. Cardoso (2018).
(1985), em Ivoti; da Casa do Professor e da Escola Rural de Timbó, em Rio dos Cedros, Santa Catarina, também na década de 1980.21

Como se tratava de edificações, eram recorrentes os argumentos para endossar tanto os pedidos de tombamento quanto os pareceres que aprovaram tais solicitações: a técnica construtiva original, que não poderia ser perdida, e a importância dos imigrantes como formadores do país. Ou seja, ao contrário dos anteriores, esses tombamentos representaram uma espécie de reconciliação entre o imigrante e o país que o acolheu, numa perspectiva que cabe muito bem no estado democrático. Isso também pode ser observado nas transformações significativas no campo do patrimônio no Brasil durante o período no qual Renato Soeiro esteve à frente do Iphan (de 1967 a 1979).

Embora esse período não tenha sido significativo em termos de tombamentos relacionados ao patrimônio do imigrante, a criação do CNRC, conforme abordado anteriormente, possibilitou a formação de quase trinta projetos desenvolvidos segundo quatro programas de estudo: Artesanato; Levantamentos socioculturais; História da ciência e da tecnologia no Brasil; e Levantamentos de documentação sobre o Brasil. Um deles é o Indústrias Familiares de Imigrantes, que criou em Orleans (município a $180 \mathrm{~km}$ de Florianópolis) um museu dedicado a equipamentos industriais utilizados por imigrantes no seu cotidiano de trabalho.

Conforme afirma a historiadora Michele Gonçalves Cardoso em sua tese de doutorado, defendida em 2018 sob o título As missões de Pe. João Leonir Dall'Alba: história, memória e produção de discursos étnicos sobre o sul do Brasil, tal ação deu visibilidade ao patrimônio do imigrante no sul do estado de Santa Catarina, endossando a produção de discursos étnicos sobre essa região do Brasil, além de evidenciar a parceria entre a recém-criada $\mathrm{FCC}^{22}$ e o lphan.

Ou seja, durante os anos 1980, embora os tombamentos relativos ao patrimônio do imigrante não tenham tido muita expressão no cenário nacional em termos quantitativos - foram apenas cinco, no total -, mostram os esforços exitosos feitos pelos agentes do patrimônio, tanto em nível nacional como regional (principalmente de catarinenses e gaúchos), para a valorização dos bens de grupos que até então não estavam no mapa da preservação.

Foram justamente as ações empreendidas em Santa Catarina durante os anos 1980, através do trabalho conjunto entre o Iphan e a FCC, que culminaram em projetos como o Roteiros Nacionais de Imigração e ampliaram a visibilidade desse patrimônio. 

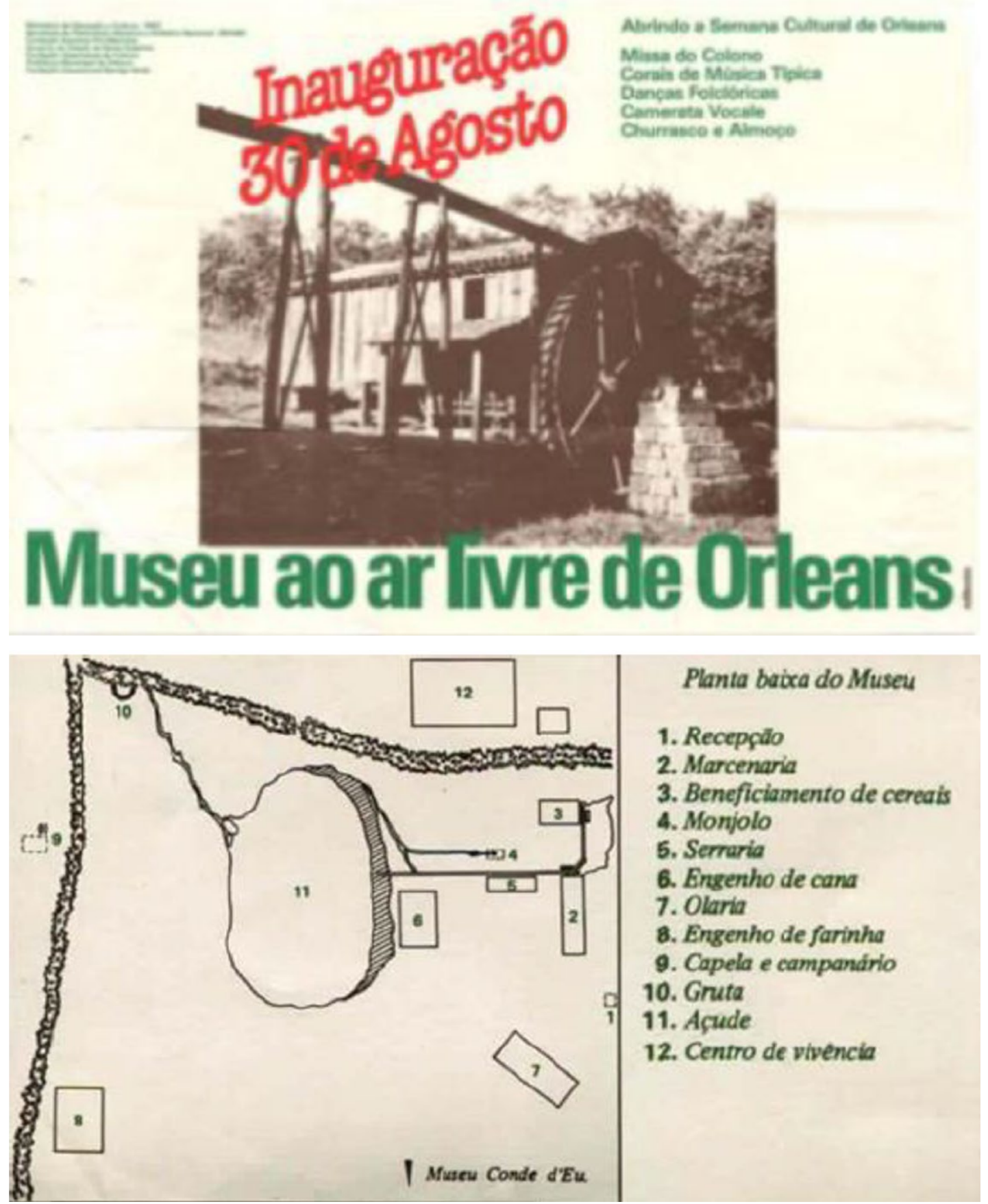

\section{Planta baixa do Museu}

1. Receppalo

2. Marcenaria

3. Beneficiamento de cereais

4. Monjolo

5. Serraria

6. Engenho de cana

7. Olaria

8. Engenho de farinha

9. Capela e campandirio

10. Gruta

11. Açude

12. Centro de vivencia

Figura 4 - Convite para a inauguração e planta baixa do Museu ao Ar Livre de Orleans. Fonte: Inventário 0750.P.282502 do Iphan. 
23. Segundo Gonçalves (2016, p.158) "Pelo decreto estadual n. 7.439, de 1979, foi instituída a Fundação Catarinense de Cultura, cujos objetivos incluíam 'promover a defesa do patrimônio histórico, artístico e cultural do Estado de Santa Catarina' (art. $2^{\circ}$, inciso VIII)".

24. Gonçalves (2016, p. 175-176).

25. Garcia Junior (2002, p. $8)$.

\section{O LUGAR DO PATRIMÔNIO DO IMIGRANTE EM SANTA CATARINA}

Foi após a instituição de uma legislação estadual sobre patrimônio - que atribuiu à FCC a responsabilidade pela preservação do patrimônio cultural no estado, em 198023- e a instalação de um escritório técnico do Iphan na capital, em 1983, que se percebeu um aumento expressivo da quantidade de tombamentos relativos aos imigrantes em âmbito estadual, que acabaram tendo projeção nacional em função da parceria com o Iphan.

Embora continuassem obedecendo aos critérios estipulados pelo DecretoLei $n^{\circ}$ 25/1937, que conferiam visibilidade ao patrimônio cujos valores fizessem sentido por seu vínculo com fatos memoráveis da história do Brasil, os bens tombados em Santa Catarina a partir da década de 1970 se voltaram para os imigrantes e seus descendentes. Nesses tombamentos estaduais, conforme aponta a historiadora Janice Gonçalves,

a história e o patrimônio de Santa Catarina foram prioritariamente interpretados na sua relação com contingentes de europeus que ocuparam e povoaram diferentes áreas do território, desde o século XVIII e sobretudo no século XIX. Assim, haveria uma Santa Catarina "alemã" no norte e no Vale do Itajaí, "italiana", no Vale do Rio dos Cedros e no sul, "polonesa" e "ucraniana" no planalto norte, "açoriana" em sua faixa litorânea, mesmo que estas designações fizessem pouco sentido para os próprios imigrantes, no momento em que chegaram ao Brasil. ${ }^{24}$

A política de preservação da FCC investiu seus primeiros vinte anos de existência em mapeamentos, inventários e pesquisas sobre o patrimônio do imigrante em Santa Catarina. Assim, ela descentralizou as ações do Iphan ao mesmo tempo que estabeleceu uma parceria entre o governo federal e o estadual. Juntas, essas instituições leram o estado catarinense como um mosaico cultural:

Afirma-se a imagem de Santa Catarina como a imagem das suas regionalidades, com seus homens típicos, significados, na maioria das vezes, nas suas origens e nos diferentes espaços aos quais estariam naturalmente ligados. Basta abrir um catálogo turístico, um livro didático, assistir a um programa televisivo, ouvir uma voz autorizada qualquer, que lá estarão como um esforço de síntese, algumas representações indefectíveis, tais como, o pescador litorâneo com sua tarrafa ao mar, o cavaleiro dos campos de Lages tendo ao fundo pinheiros em sombra, pessoas no Vale do Itajaí, com sua germanidade exteriorizada em trajes típicos e arquitetura enxaimel. Enfim, imagens e textos de habitantes típicos, de espaços regionalizados, que ganham organicidade em uma unidade geográfica denominada Santa Catarina. ${ }^{25}$ 
Mas, afinal, de que forma o patrimônio serviu como instrumento para legitimar a compreensão de Santa Catarina como um mosaico cultural - tão difundida no próprio estado e em projetos de âmbito nacional?

De um lado, pode-se dizer que as narrativas produzidas pela historiografia tradicional sobre a imigração em Santa Catarina endossaram a importância do patrimônio do imigrante alemão e italiano no estado e os apresentaram como responsáveis pelo desenvolvimento regional tão almejado pela elite catarinense. De outro, houve o investimento do estado, a partir dos anos 1980, em pesquisas e estudos que colocaram em evidência esse patrimônio.

Embora o Iphan se fizesse presente no estado desde 1938, com os tombamentos federais, só passou a contar com um escritório em Santa Catarina em 1983, sob a chefia do arquiteto Dalmo Vieira Filho. Ele foi fundamental para a consolidação dessa parceria entre Iphan e o governo do estado, bem como para os rumos da política pública de preservação do patrimônio do imigrante em Santa Catarina e para sua projeção nacional, principalmente quando esteve à frente do Departamento de Patrimônio Material do Iphan. Ao que tudo indica, o primeiro trabalho da FCC em relação à imigração, segundo a arquiteta Fátima Regina Althoff, foi um levantamento do patrimônio de origem alemã realizado pelos técnicos do órgão através de "um grande levantamento fotográfico para colher material visual para o primeiro seminário sobre arquitetura de influência alemã no estado, o Seminário sobre Desenvolvimento Urbano e Preservação do Patrimônio Histórico, em novembro de $1981 " .26$ Esse levantamento, iniciado nos municípios da Grande Florianópolis, como São Pedro de Alcântara, se estendeu para as regiões do Vale do Itajaí, Norte e Planalto Norte, nas quais estão presentes tanto a arquitetura rural como a urbana.

A partir desse trabalho inicial de mapeamento da arquitetura teuta, outras ações ganharam expressão, como o Inventário das Correntes Migratórias. ${ }^{27}$ Iniciado em julho de 1983 e concluído em 1984, o projeto promoveu o cadastramento (Figura 5) de edificações importantes no contexto das várias etnias que compõem o panorama cultural catarinense: o povoamento açoriano lem Laguna e São Francisco do Sul), a colonização alemã (em Joinville e São Bento do Sul) e a italiana (em Urussanga e Nova Veneza). ${ }^{28}$

Objetivo específico do Projeto Inventário das Correntes Migratórias ${ }^{29}$ era inventariar: edificações de "notável qualidade estética" ou particularmente representativas de determinada época ou estilo; edificações intimamente relacionadas a fatos históricos ou a pessoas de excepcional notoriedade; sítios ou paisagens agenciados pela indústria humana que possuíssem especial atrativo; edificações e logradouros públicos já consagrados na memória coletiva como ambientes tradicionais; edificações de valor ambiental urbano; edificações que,
26. Althoff (2008, p. 82).

27. Cf. Fundação Catarinense de Cultura (1983).

28. De Luca (2007, p. 67).

29. Cf. Fundação Catarinense de Cultura (198-). 
30. Simon (2000, p. 17)

31. Ibid. (p. 18). por sua localização na malha urbana e aérea, fossem facilmente reciclados; e caminhos, estradas e ambientes vinculados à história local. ${ }^{30}$

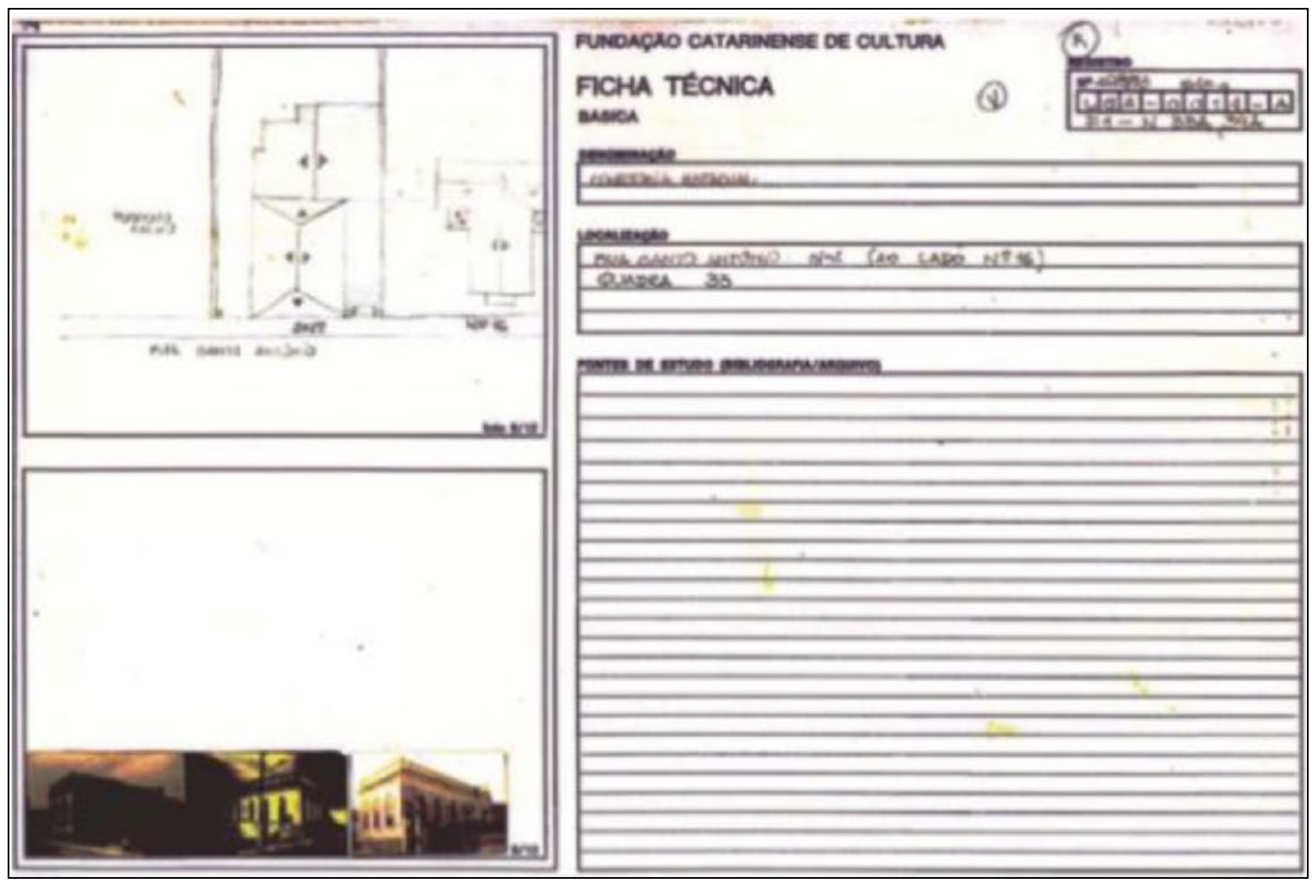

Figura 5 - Ficha técnica do Inventário das Correntes Migratórias. Fonte: Arquivo da Diretoria de Patrimônio Cultural da FCC.

Foi por meio dessa incursão ao campo que se deu uma das primeiras caracterizações do patrimônio catarinense. Segundo a arquiteta Lilian Mendonça Simon, "o acervo inventariado caracteriza-se basicamente pela ausência de monumentalidade e diversidade de técnicas construtivas e de tipologias arquitetônicas", descrição encontrada repetidamente nos textos sobre o patrimônio de Santa Catarina. ${ }^{31}$

Outro projeto, chamado Inventário de Emergência, foi realizado por conta da enchente de 1983, que inundou grande parte das regiões do estado catarinense, tendo sido responsável por mapear 43 municípios vitimados (Figura 6). O saldo dessa ação foi o destaque dado à arquitetura europeia através do tombamento, já no início dos anos 1990, de aproximadamente duzentos imóveis, tanto no meio urbano quanto no rural.

Desses duzentos bens, oitenta faziam referência à arquitetura enxaimel. Por conta disso, o órgão de preservação federal propôs a ampliação do inventário para a área de imigração alemã nas zonas rurais de Blumenau, Pomerode, Timbó, Indaial, Joinville, São Bento do Sul e Jaraguá do Sul. Desse inventário, 
então, surgiu o Plano de Desenvolvimento e Valorização do Legado Construído pelo Imigrante Alemão em Santa Catarina, de 1986.32

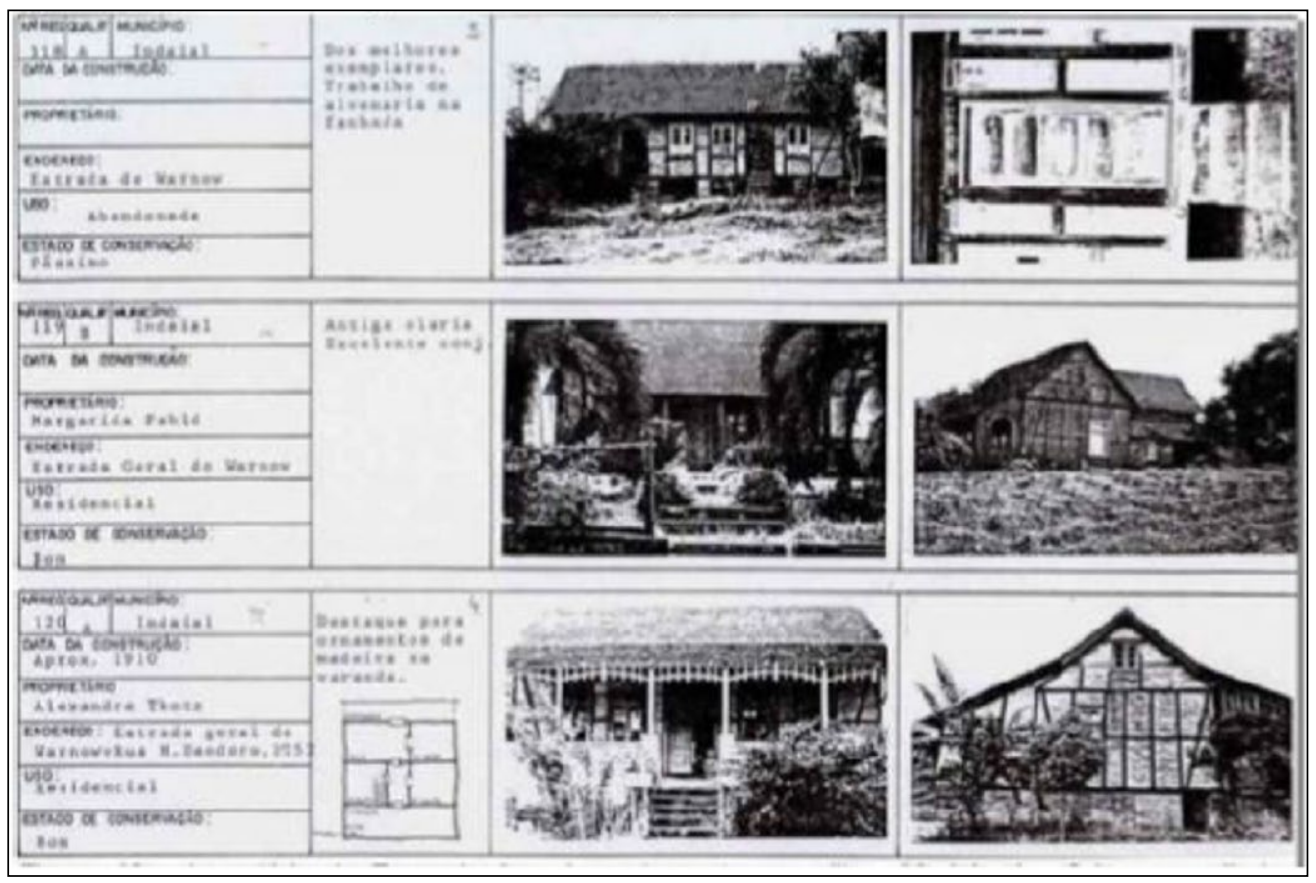

Figura 5 - Ficha técnica do Inventário das Correntes Migratórias. Fonte: Arquivo da Diretoria de Patrimônio Cultural da FCC.

Esse documento teve importância significativa nos rumos da preservação do patrimônio do imigrante, não apenas por atentar para as edificações, mas também por criar parâmetros para o desenvolvimento e a valorização da área de proteção cultural e paisagística, definindo seus limites, regulamentando seu uso e sua ocupação. Além disso, o caráter vanguardista do projeto se deve ao fato de sugerir para o estado de Santa Catarina que o patrimônio cultural do imigrante alemão pudesse se tornar um atrativo turístico a partir da instituição de roteiros culturais.

$\bigcirc$ documento Plano de Desenvolvimento e Valorização do Legado Construído pelo Imigrante Alemão em Santa Catarina deliberou sobre três aspectos relativos à paisagem rural do patrimônio em questão: a ocupação e o uso do solo, as edificações e os pontos de produção cultural.

Em relação ao solo, definiu as áreas agrícolas como zonas especiais, delimitando a área dos lotes e cotas para as novas construções. Também definiu gabarito para as edificações e sugeriu que as propriedades de valor histórico integrassem rotas turísticas. A partir desses critérios, o documento criou uma área
32. Instituto do Patrimônio Histórico e Artístico Nacional; Fundação Nacional Pró-Memória. (1986). 
33. Instituto do Patrimônio Histórico e Artístico Nacional; Fundação Nacional Pró-Memória (1987, p.1). de proteção cultural e paisagística denominada Roteiro Cultural, fixando seus limites e regulamentando seu uso e ocupação:

Santa Catarina possui sem dúvida um potencial turístico que associa paisagens naturais de rara beleza ao patrimônio histórico-cultural singular. É possuidora de cidades de pequeno e médio porte marcadas pelas construções típicas dos imigrantes que deixaram sua marca não só na arquitetura, mas também nos seus hábitos alimentares, festas, costumes, modos de fazer e de viver. Possuem ainda cenários reais e pequenos vilarejos. É nessa valorização do acervo cultural ainda existente que se baseia o projeto dos Roteiros Culturais. ${ }^{33}$

A justificativa que dotou de potencial turístico o patrimônio cultural localizado em áreas rurais e relacionado aos imigrantes começou a ser valorizada formalmente a partir das discussões feitas pela FCC. Mais tarde, os patrimônios foram integrados aos programas da Agência de Desenvolvimento do Turismo de Santa Catarina (Santur), compreendidos como atrativos turísticos alternativos ao já consagrado turismo de praia.

Propôs-se um Roteiro Cultural para a região do Vale do Itajaí e outro para a região Nordeste, detalhando em ambos: as unidades a serem tombadas; as unidades a serem revitalizadas e suas propostas de utilização; a identificação de produtos regionais e unidades de comercialização; a identificação de unidades rurais exemplares pela ótica museológica; e a identificação de áreas de interesses paisagísticos.

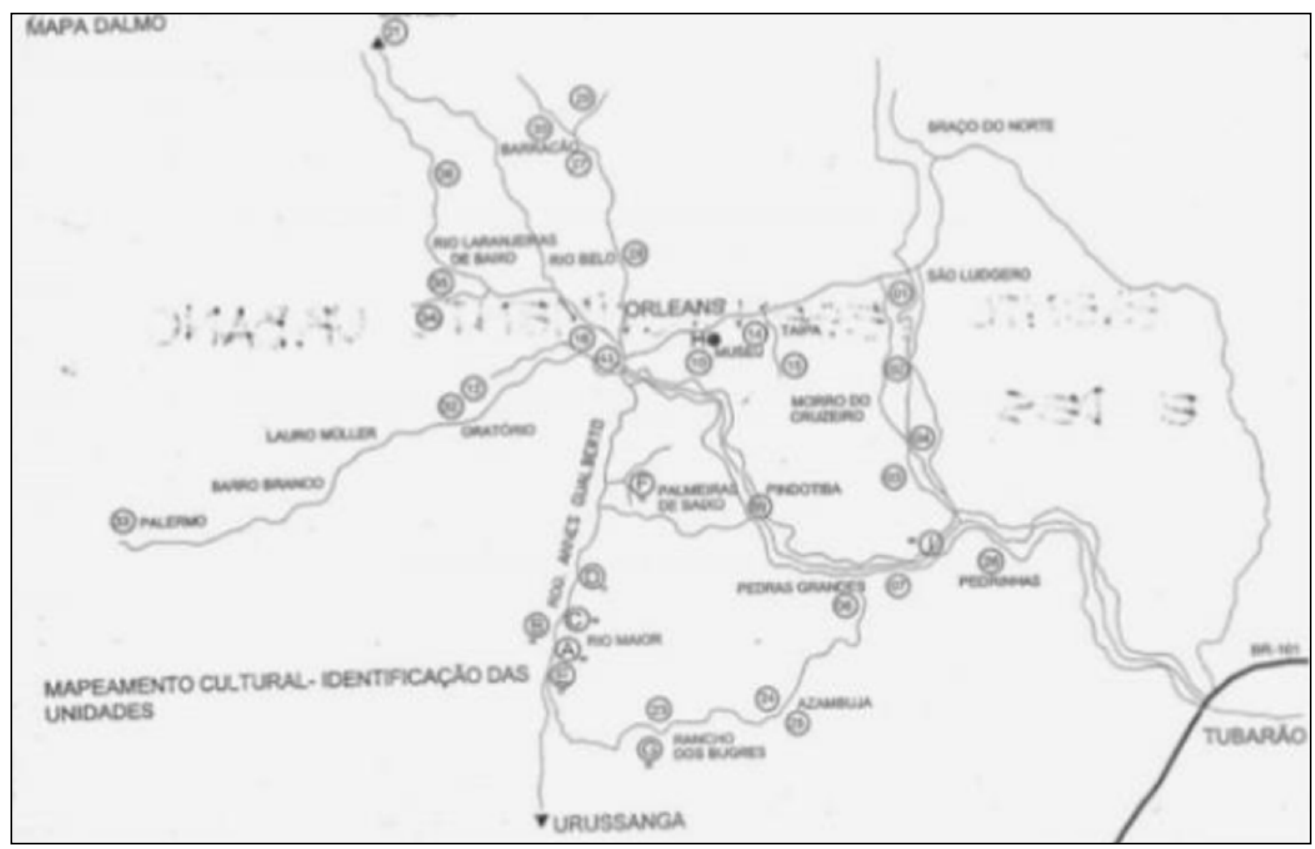

Figura 7 - Roteiros Culturais: mapeamento das unidades. Fonte: Arquivo da Diretoria de Patrimônio Cultural da FCC. 
No entanto, os técnicos da FCC, ao perceber que a área de imigração alemã era objeto de estudos bastante detalhados por parte da $10^{a}$ Coordenadoria Regional do Iphan, desenvolveram, em conjunto com a direção deste órgão, uma proposta de trabalho voltada para a colonização italiana do sul do estado, "pois até então ela carecia de ações efetivas e de propostas concretas no que se refere à valorização de seu patrimônio cultural e ambiental". ${ }^{34}$

Surgiu então, no segundo semestre de 1987, o projeto Roteiros Culturais Sul, em parceria com a FCC, o Ministério da Cultura e as prefeituras municipais, cuja área de abrangência foi a região sul de Santa Catarina. Seu principal objetivo era presenvar e revitalizar o patrimônio cultural com fortes influências da colonização italiana, fomentando o desenvolvimento de condições favoráveis à manutenção das produções caseiras e garantindo retorno social, cultural e financeiro às populações envolvidas.

A principal justificativa desse projeto estava ancorada na importância que os grupos étnicos tinham nas ações da FCC (como no Inventário das Correntes Migratórias), pelos seguintes aspectos: necessidade de diminuição do êxodo rural; ampliação da comercialização dos produtos fabricados nas propriedades rurais de toda a região; ampliação da oferta de atrativos turísticos em todo estado catarinense, especialmente nos meses de inverno; e criação de novas oportunidades de trabalho e captação de recursos em toda a região.

Foi selecionada, como ponto de partida, a cidade de Laguna (mais especificamente seu centro histórico, tombado nacionalmente), passando por Orleans (Museu ao Ar Livre), Pedras Grandes, Urussanga, Criciúma e Nova Veneza. A partir de um formulário de identificação de roteiro cultural (sem dúvida embasado naquele utilizado pelo International Council on Monuments and Sites), elaborou-se uma ficha que abordava os elementos mais significativos dos percursos, com cinco propostas: Roteiro 1 - Tubarão/Urussanga via Pedras Grandes, que deu ênfase ao trajeto histórico percorrido pelos imigrantes; Roteiro 2 - Urussanga urbano/rural, que enfatizou o patrimônio das duas áreas, com destaque para a paisagem rural das localidades; Roteiro 3 - Tubarão/Urussanga via Morro da Fumaça, que destacou o caminho rural; Roteiro 4 - Urussanga/Criciúma/Nova Veneza, que fez referência aos bens culturais das cidades; e, por fim, o Roteiro 5 - Tubarão/Urussanga via Gravatal e Orleans, que destacou o Museu ao Ar Livre.

As ações implementadas pela FCC e pelo Iphan em Santa Catarina descritas até aqui deram visibilidade ao patrimônio no estado, seja no levantamento fotográfico realizado em áreas de imigração alemã, que deu suporte ao Congresso de Desenvolvimento Urbano do Estado (1 983); no Inventário das Correntes Migratórias (1984); nos Inventários de Emergência (1984); no projeto Roteiros Culturais, proposto pela Fundação Nacional Pró-Memória e pela FCC (1987); ou no projeto Roteiros 
Culturais Sul (1987), realizado também em parceria entre a Fundação Nacional Pró-Memória e a FCC. Em todos o alvo da preservação foi o patrimônio dos imigrantes, representado basicamente pelas imigrações alemã e italiana.

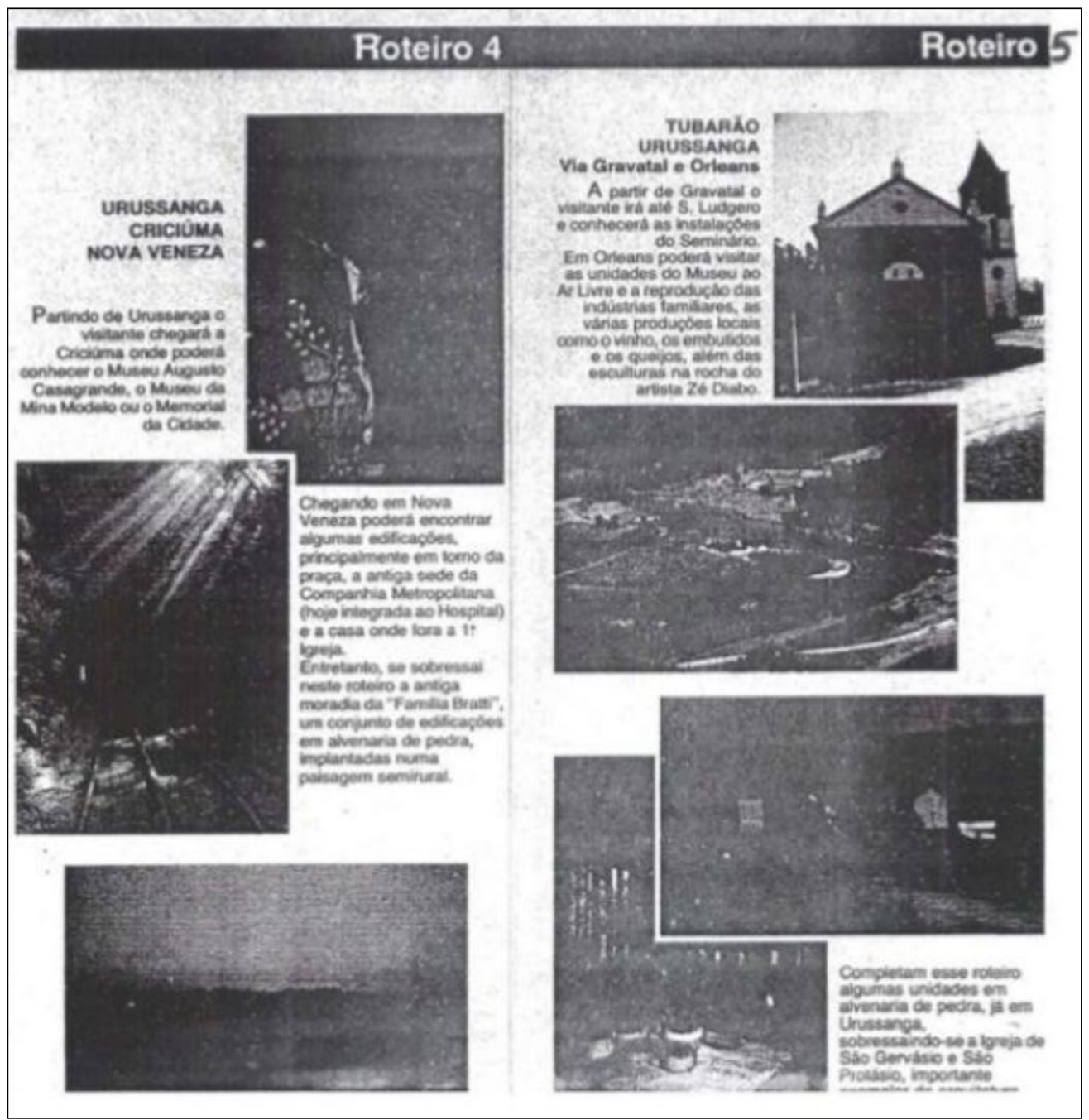

Figura 7 - Roteiros Culturais: mapeamento das unidades. Fonte: Arquivo da Diretoria de Patrimônio Cultural da FCC.

Outras ações desenvolvidas mais tarde, como o Projeto de Resgate do Patrimônio Histórico da FCC (2006) e o ldentidades (2008), corroboraram essa prática de valorização do patrimônio do imigrante e chegaram ao ápice em 2007, quando a FCC junto ao Iphan e seus parceiros lançaram o projeto Roteiros Nacionais de Imigração, coroando uma políitica de preservação do patrimônio étnico, conforme sinalizado na introdução deste artigo. 
Se, por um lado, a trajetória descrita mostra que o estado teve projetos ou ações de preservação que valorizaram o patrimônio do imigrante, foi apenas com a política implementada pelo Iphan - com o projeto Roteiros Nacionais de Imigração, sob a coordenação do arquiteto Dalmo Vieira - que o trabalho realizado ao longo de vinte anos teve visibilidade e repercussão nacional.

\section{SANTA CATARINA E A CONSOLIDAÇÃO DE UM PATRIMÔNIO CALCADO EM VALORES ÉTNICOS}

O panorama abordado até aqui permite perceber que as políticas públicas de preservação do patrimônio cultural em Santa Catarina realizadas conjuntamente pelo Iphan e pela FCC durante os anos 1980 contribuíram para a criação de narrativas que privilegiaram o componente étnico de grupos de imigrantes como representativo do patrimônio cultural da imigração no Brasil. Mais do que isso, forneceram, através de pesquisas e inventários, as bases para o projeto Roteiros Nacionais de Imigração que, de certa forma, transformou-se em referência de preservação do patrimônio do imigrante no país.

Ao privilegiar essa escolha, foram permitidas a entrada e a visibilidade de novos atores sociais em um cenário no qual até então não eram contemplados, pois a lógica da política de preservação do patrimônio recaía sobre valores relacionados ao passado colonial do Brasil. Por outro lado, por se tratar de uma escolha, também minimizou a importância do patrimônio cultural de outros grupos étnicos que migraram para o Brasil, bem como a diversidade do seu patrimônio.

Ao construir uma narrativa sobre o patrimônio cultural do imigrante europeu, notadamente alemão e italiano, que se localiza no estado de Santa Catarina, o Iphan não apenas o fez de forma generalizada como apresentou esse patrimônio e os seus personagens centrais como frutos de um tempo interditado, suspenso: um tempo pretérito marcado pela idealização estereotipada do que é ser imigrante no Brasil, muito distante da dinâmica cotidiana da vida contemporânea. ${ }^{35}$

Tanto o tombamento dos 61 bens que compõem o projeto Roteiros quanto a Chancela da Paisagem Cultural Brasileira atribuída ao núcleo rural que também integra a região se constituíram em mais dois instrumentos que ajudaram a endossar uma identidade para o Brasil, marcada, neste caso, por grupos representados por alemães e italianos. As políticas públicas ligadas à instituição do patrimônio cultural criaram uma identidade étnica para o país a partir da atribuição de determinados
35. Estudo sobre a construção de uma visualidade da imigração pode ser encontrado no texto "Cartografia do patrimônio da imigração no Brasil: o caso do projeto Roteiros Nacionais de Imigração/SC" (Pistorello, 2017). 
valores aos bens culturais ligados à imigração e, sobretudo, construíram essa identidade a partir dos instrumentos de salvaguarda do patrimônio. Esse projeto, fruto das investidas realizadas pelo Iphan e pela FCC nos anos 1980, ao ser problematizado, diz muito sobre a política de preservação do patrimônio cultural no Brasil e sua relação com os estados brasileiros.

Como se percebe, o Iphan, logo após sua fundação, já atribuía valor ao patrimônio do imigrante através de tombamentos. Com exceção de um único bem relacionado ao patrimônio da imigração japonesa no Brasil, todos os outros tombamentos até os anos 2000, embora quantitativamente pouco expressivos, foram representativos dos imigrantes alemães e italianos e se localizavam especificamente nos estados do Rio Grande do Sul e Santa Catarina. Foi na década de 2000, com o lançamento do projeto Roteiros Nacionais de Imigração, que se considerou a indicação de tombar 59 bens culturais, um núcleo urbano e um rural. Isso porque a valorização do patrimônio do imigrante passou a ter maior visibilidade devido à expressiva quantidade de bens indicados para tombamento e seu impacto na lógica de preservação.

Importa destacar que a valorização do patrimônio do imigrante pelo Iphan não se deu apenas através dos instrumentos de salvaguarda, mas também de ações pontuais, como a criação do Museu ao Ar Livre de Orleans que, em funcionamento até os dias atuais, tem o objetivo de abrigar objetos relativos ao trabalho cotidiano de imigrantes e expô-los para a comunidade. A análise das justificativas dos processos de tombamento ocorridos na década de 1930, 1960, 1980 e 2000 permitiu perceber que o patrimônio do imigrante foi valorizado de forma diferente ao longo do tempo, ao sabor do contexto político-cultural que se desenhava e que impactou o órgão nacional de preservação.

A dissimulação do patrimônio dos imigrantes alemães nominada de Palácio dos Príncipes, tombado em 1938; a justificativa que atribui à paisagem do Cemitério Protestante o motivo central do seu tombamento, em 1962; os tombamentos realizados na década de 1980 (Casa Presser, Casa do Professor, Escola Rural, Casa da Neni, Ponte do Imperador e Conjunto Urbano de Antônio Prado), que valorizaram explicitamente o trabalho do imigrante e seu patrimônio; e os 61 tombamentos realizados em 2012 apontam um sensivel deslocamento para o fato de que o imigrante e seu patrimônio passaram a ter importância na política de preservação nacional. Assim, a criação do projeto Roteiros, na verdade, respaldou o grande número de tombamentos dos bens relativos ao patrimônio do imigrante realizados nas duas últimas décadas, principalmente no estado catarinense. $\bigcirc$ lançamento do projeto em 2007 significou, além da sua formalização através da assinatura do termo de compromisso, uma arrancada rumo à maratona de tombamentos que deveriam 
acontecer a partir dali. $\bigcirc$ que garantiu o sucesso da primeira etapa do processo foi dar visibilidade ao patrimônio para depois torná-lo atrativo turístico.

No que tange à construção de uma identidade étnica para o Brasil, o projeto Roteiros escolheu a qual imigrante dar visibilidade. Apesar de ressaltar que o patrimônio cultural representativo da imigração polonesa e ucraniana teria destaque, o que ficou mesmo em evidência foi o patrimônio do imigrante alemão e italiano, nesta ordem de importância, tornando ausentes outros processos migratórios.

Assim, pode-se inferir que o imigrante representado pelo projeto foi forjado. Não se trata de tomar como referência qualquer outro imigrante, mas um que atenda às demandas dos seus idealizadores. $\bigcirc$ imigrante do projeto não é mais aquele que na década de 1930 foi considerado pelo estado o principal alvo da política nacionalista de Vargas. Tampouco se trata do imigrante que durante a década de 1940, com a iminência da Segunda Guerra, foi considerado um perigo. Pode-se dizer também que o projeto não se apropriou tão somente da imagem do imigrante construída pelos órgãos de preservação dos anos 1980, nos quais as justificativas para o tombamento do patrimônio versavam sobre a sua reabilitação na sociedade democrática que surgia.

Pode-se afirmar, então, que o imigrante do projeto foi a síntese das narrativas produzidas ao longo dos tempos anteriores mais a especificidade exigida pelas demandas contemporâneas, idealizando o imigrante alemão ou italiano que possuía uma pequena propriedade rural, trabalhava nela de forma quase exclusivamente artesanal e convivia harmoniosamente no seu território. Nestas condições, produziuse um patrimônio ímpar, original e digno de preservação. Para que essa harmonia não fosse interrompida, o cenário não se alterasse e esse patrimônio não fosse perdido, o estado ofereceu, por meio do projeto Roteiros, a transformação desse patrimônio em produtos turísticos. Nesse sentido, os bens tombados e a paisagem cultural da imigração se apresentam como objetos de consumo, estreitando uma relação importante entre patrimônio cultural e turismo, quando problematizada.

Por fim, percebe-se um redirecionamento das políticas públicas do Iphan nos anos 1980 e seus desdobramentos nos diversos estados brasileiros que, a sua maneira, endossaram essas novas perspectivas. Seja através de demandas historicamente produzidas em âmbito regional e/ou pela existência de relações políticas que permitiram que essas demandas chegassem até a centralidade do poder decisório do Iphan, o fato é que houve a possibilidade de dar visibilidade a outros atores sociais que até então estavam fora dos quadros contemplados pelo órgão - muito embora a ênfase tenha sido dada exclusivamente ao patrimônio europeu, como mencionado ao longo desta reflexão. 
No entanto, se de um lado o extenso trabalho realizado ao longo da década de 1980 pelas instituições de preservação catarinenses (Iphan e FCC) culminou no projeto Roteiros Nacionais de Imigração e serviu como referência para outros estados, por outro, a forma como essa valorização foi materializada não diferiu substancialmente das práticas anteriores, quando a preservação do patrimônio se restringia a pedra e cal.

Ainda que o discurso da diversidade cultural tenha amparado as práticas de preservação nas experiências apresentadas e houvesse tentativas de apreender essa diversidade, percebe-se que o patrimônio cultural da imigração ainda estava bastante centrado nas edificações.

Os projetos desenvolvidos pelo Iphan e pela FCC em Santa Catarina nos anos 1980 (proposição de inventários, roteiros culturais etc.) tiveram como ponto de partida a cultura material dos grupos pesquisados - representada por suas moradias, casas de comércio, espaços educacionais, religiosos etc. Pouco se avançou no sentido de construir instrumentos - para além do tombamento - que pudessem ser utilizados para dar conta das muitas manifestações culturais dos grupos inventariados. Mesmo o projeto Roteiros, que partiu do contexto da década de 1980 e se consolidou nos anos 2000, não conseguiu ir além dessa proposta. Apesar de o projeto fazer referência à paisagem cultural da imigração e à importância do seu patrimônio imaterial, o dossiê de tombamento não explorou essas possibilidades.

Essa perspectiva, que canoniza a arquitetura como o próprio patrimônio do imigrante, também pode endossar uma narrativa acerca do patrimônio da imigração que se apresenta de forma apartada do contexto social, gerando uma percepção de que o imigrante referenciado seja aquele que ainda vive no século XIX, com os mesmos recursos, e convive harmoniosamente no seu território.

Nesse sentido, o grande desafio de pensar o patrimônio da imigração no Brasil, como é o caso do patrimônio cultural em geral, talvez seja incorporar a ideia da diversidade nos instrumentos de proteção do patrimônio cultural, como tem sido recorrente em algumas práticas culturais. Neste caso específico, a Chancela da Paisagem Cultural Brasileira parece ser um instrumento que, se potencializado, poderia dar conta de experiências como as da imigração, pois trata especificamente das relações entre os grupos humanos e seu território e, portanto, é uma possibilidade de lidar com a dinâmica dessa relação. 


\section{REFERÊNCIAS}

FONTES IMPRESSAS

FUNDAÇÃO CATARINENSE DE CULTURA; UNIVERSIDADE FEDERAL DE SANTA CATARINA. Apresentação do relatório do inventário de emergência. Florianópolis: FCC, [198-].

FUNDAÇÃO CATARINENSE DE CULTURA. Programa Preservação da Memória Cultural. Projeto Inventário das Correntes Migratórias. Florianópolis: FCC, 1983.

FUNDAÇÃO CATARINENSE DE CULTURA. Projeto Roteiros Culturais Sul. Florianópolis: FCC, 1987.

INSTITUTO DO PATRIMÔNIO HISTÓRICO E ARTÍSTICO NACIONAL. Inventário 0750.P.2825.02. Arquivo Noronha Santos, Rio de Janeiro. [198-?]

INSTITUTO DO PATRIMÔNIO HISTÓRICO E ARTÍSTICO NACIONAL. Processo de tombamento do Cemitério Protestante. Joinville, n. 659-T62, Brasília, 1962.

INSTITUTO DO PATRIMÔNIO HISTÓRICO E ARTÍSTICO NACIONAL. Processo de tombamento do Bosque Schmalz. Joinville, n. 756-T65. Brasília, 1965.

INSTITUTO DO PATRIMÔNIO HISTÓRICO E ARTÍSITICO NACIONAL; FUNDAÇÃO NACIONAL PRÓ-MEMÓRIA. Plano de desenvolvimento e valorização do legado construído pelo imigrante alemão em Santa Catarina. Florianópolis, [1986].

LIVROS, ARTIGOS E TESES

ALTHOFF, Fátima Regina. Políticas de preservação do patrimônio edificado catarinense: a gestão do patrimônio urbano de Joinville. 2008. Dissertação (Mestrado em Arquitetura) Universidade Federal de Santa Catarina, Florianópolis, 2008.

BOURDIEU, Pierre. Razões práticas: sobre a teoria da ação. Campinas: Papirus, 1996.

CARDOSO, Michele Gonçalves. As missões de Pe. João Leonir Dall'Alba: história, memória e produção de discursos sobre o sul do Brasil. 2018. Tese (Doutorado em História) - Universidade do Estado de Santa Catarina, Florianópolis, 2018. 
CHUVA, Márcia Regina Romeiro. Os arquitetos da memória: sociogênese das práticas de preservação do patrimônio cultural no Brasil (anos 1930-1940). Rio de Janeiro: Editora da UFRJ, 2009.

CHUVA, Marcia Regina Romeiro. A preservação do patrimônio cultural no Brasil: uma perspectiva histórica, ética e política. In: CHUVA, Márcia Regina Romeiro; NOGUEIRA, Antônio Gilberto Ramos de (orgs.). Patrimônio cultural: políticas e perspectivas de preservação no Brasil. Rio de Janeiro: Mauad X: Faperj, 2012. p. 67-78

DE LUCA, Virgínia Gomes. O patrimônio arquitetônico e a paisagem cultural em sítios bistóricos rurais de imigração italiana. 2007. Dissertação (Mestrado em Arquitetura) Universidade Federal de Santa Catarina, Florianópolis, 2007.

FONSECA, Maria Cecília Londres. O patrimônio em processo: trajetória da política federal de preservação no Brasil. 2. Ed. Rio de Janeiro: Editora UFRJ/Minc-Iphan, 2005.

GARCIA JUNIOR, Edgar. Práticas regionalizadoras e o mosaico cultural catarinense. 2002. Dissertação (Mestrado em História) - Universidade Federal de Santa Catarina, Florianópolis, 2002.

GONÇALVES, Janice. Figuras de valor: patrimônio cultural em Santa Catarina. Itajaí: Casa Aberta, 2016.

INSTITUTO DO PATRIMÔNIO HISTÓRICO E ARTÍSTICO NACIONAL. Memória e preservação: Antônio Prado - RS. Brasília, DF: Iphan: Programa Monumenta, 2009. (Preservação e Desenvolvimento, 16).

INSTITUTO DO PATRIMÔNIO HISTÓRICO E ARTÍSTICO NACIONAL. Roteiros Nacionais de Imigração: Santa Catarina. Vol. 1. Brasília, DF: Iphan, 201.

INSTITUTO DO PATRIMÔNIO HISTÓRICO E ARTÍSTICO NACIONAL. Planos de Ação para cidades históricas. 1 ? Oficina de Capacitação. Brasília, DF: Iphan, 2009.

MACHADO, Diego Finder. Um lugar para recordar a imigração no sul do Brasil: debates políticos e intelectuais na criação do Museu Nacional de Imigração e Colonização em Joinville/ SC (1949-1957). Patrimônio e Memória, Assis, v. 15, n. 2, p. 99-128, 2019.

MENESES, Ulpiano Toledo Bezerra de. O campo do patrimônio cultural: uma revisão de premissas. In: INSTITUTO DO PATRIMÔNIO HISTÓRICO E ARTÍSTICO NACIONAL. I Fórum Nacional do Patrimônio Cultural: Sistema Nacional de Patrimônio Cultural: desafios, estratégias e experiências para uma nova gestão: Ouro Preto - MG, 2009. Brasília, DF: Iphan, 2012. (Anais 2, v. 1). p. 25-39. 
PISTORELLO, Daniela. “O Brasil da diversidade?”: patrimônio e paisagem cultural no projeto Roteiros Nacionais de Imigração. 2015 Tese (Doutorado em História) - Universidade Estadual de Campinas, Campinas, 2015.

PISTORELLO, Daniela. Cartografia do patrimônio da imigração no Brasil: o caso do projeto Roteiros Nacionais de Imigração/SC. In: GONÇALVES, Janice (org.). Patrimônio imaginado: fotografia e patrimônio cultural. São Leopoldo: Oikos, 2017. p. 11-44.

RADUM, Denis Fernando. O (des)tombamento em questão: (des)patrimonialização de bens culturais tombados pelo órgão federal de preservação no Brasil (1937-2015). 2016. Dissertação (Mestrado em Patrimônio Cultural e Sociedade) - Universidade da Região de Joinville, Joinville, 2016.

RUBINO, Silvana. As fachadas da história: os antecedentes, a criação e os trabalhos do Serviço do Patrimônio Histórico e Artístico Nacional, 1937-1968. 1991. Dissertação (Mestrado em Antropologia) - Universidade Estadual de Campinas, Campinas, 1991.

SIMON, Lilian Mendonça. Documentação e monitoramento de sítios urbanos históricos: com o apoio do cadastro técnico multifinalitário e da fotogrametria digital: estudo de caso: Laguna. 2000. Dissertação (Mestrado em Arquitetura) - Universidade Federal de Santa Catarina, Florianópolis, 2000.

WEIMER, Günter. Arquitetura popular brasileira. São Paulo: Martins Fontes, 2005.

WEISSHEIMER, Maria Regina. A paisagem cultural e os Roteiros Nacionais de Imigração. In: INSTITUTO DO PATRIMÔNIO HISTÓRICO E ARTÍSTICO NACIONAL. I Fórum Nacional do Patrimônio Cultural: Sistema Nacional de Patrimônio Cultural: desafios, estratégias e experiências para uma nova gestão: Ouro Preto - MG, 2009. Brasília, DF: Iphan, 2012. (Anais 2, v. 2). p. 224-232.

WEISSHEIMER, Maria Regina; VIEIRA, Dalmo (orgs.). O patrimônio Cultural da Imigração em Santa Catarina. In: INSTITUTO DO PATRIMÔNIO HISTÓRICO E ARTÍSTICO NACIONAL. Brasília, DF: Iphan, 2011.

Artigo apresentado em: $31 / 5 / 2020$. Aprovado em: 12/8/2020. (cc) BY

All the contents of this journal, except where otherwise noted, is licensed under a Creative Commons Attribution Licens 